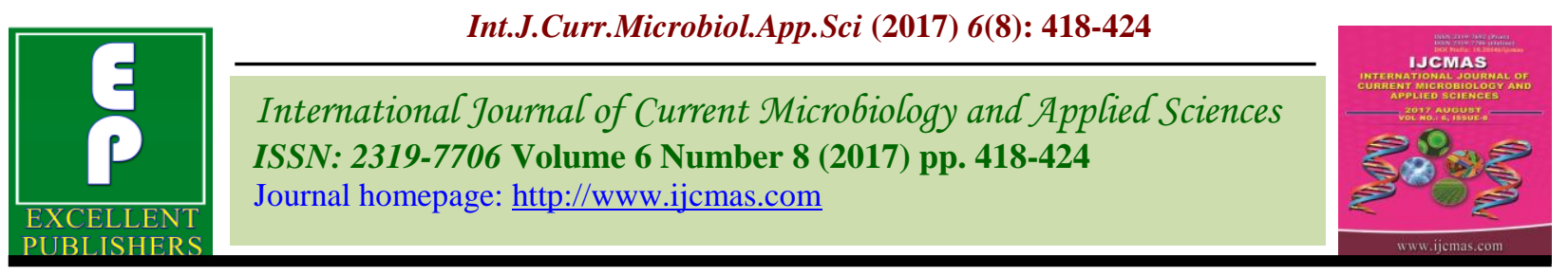

Original Research Article

https://doi.org/10.20546/ijcmas.2017.608.055

\title{
Genotype x Environment Relations and Stability Analysis in Different Land Races of Maize (Zea mays L.)
}

\author{
R.A. Gami ${ }^{*}$, J.M. Patel $^{2}$, S.M. Chaudhary ${ }^{1}$ and G.K. Chaudhary ${ }^{3}$ \\ ${ }^{1}$ Maize Research Station, S.D. Agricultural University, Bhiloda-383 245 (Gujarat), India \\ ${ }^{2}$ Wheat Research Station, S.D. Agricultural University, Vijapur (Gujarat), India \\ ${ }^{3}$ Department of Agriculture Statistics, CPCA, S.D. Agricultural University, \\ Sardarkrushinagar (Gujarat), India \\ *Corresponding author
}

\section{A B S T R A C T}

\begin{tabular}{l}
\hline Ke y w or d s \\
Zea mays L., \\
Land race, GxE \\
interaction and \\
Stability. \\
\hline Article Info \\
\hline $\begin{array}{l}\text { Accepted: } \\
\text { 04 June } 2017 \\
\text { Available Online: } \\
\text { 10 August } 2017\end{array}$ \\
\hline
\end{tabular}

\section{Introduction}

Maize (Zea mays L.; $2 \mathrm{n}=20$ ) is one of the most important economic cereal crops of the world. It was domesticated over the past 10,000 years from the grass teosinte in Central America (Doebley et al., 2006) and has been subject to cultivation and selection ever since. It ranks one of the three important cereal crops in the world after wheat and rice for production and consumption. Maize is a monoecious plant, that is, the reproductive organs are partitioned into separate pistillate (ear), the female flower and staminate (tassel) inflorescence, the male flower on the same plant. It has a determinate growth habit and the shoot terminates into the inflorescences bearing staminate or pistillate flowers (Dhillon and Prasanna, 2001). Maize is the staple food of Asian people and is also utilized in starch, oil, food and feed industries. It is used as the major cereal in the local population in the form of local/stable foods for daily diet. Green cobs are either roasted or boiled and then consumed by people. It is also a good feed for poultry, 
piggery, swine, fish and other domestic animals. It supplies raw materials for manufacturing various industrial products. Maize grain contains about $70 \%$ starch, $9.9 \%$ protein, $4 \%$ oil and $2.7 \%$ crude fiber.

Stability of genotypes depends on maintaining certain morphological and physiological attributes steady and allowing others to vary, resulting in predictable $\mathrm{G} \times \mathrm{E}$ interaction for yield. Study of individual yield components can lead to simplification in genetic explanation of yield stability and hence are valuable to breeders in prediction and determination of the effects of the environments. Phenotype may be defined as a linear function of genotype $(\mathrm{G})$, environment (E) and $(\mathrm{G} \times \mathrm{E})$ interaction effect. Relative importance of main and interaction effects may vary from genotype to genotype and with environments. Thus, the study of $G \times E$ interaction serves as a guide and helps in identifying suitable genotypes for various environmental niches.

\section{Materials and Methods}

The experiment was conducted in three consecutive years in randomized block design at Maize Research Station, S. D. Agricultural University, Bhiloda during kharif 2014- 2016 to evaluate 51 different land races of maize. Each genotype was grown in two rows of $3 \mathrm{~m}$ length with $60 \times 20\left(\mathrm{~cm}^{2}\right)$ spacing. The size of net plot was $3.6 \mathrm{~m}^{2}$ and each plot $>90$ per cent plant population were maintained. The data were recorded from five randomly selected plants from each entry in each replication for plant height $(\mathrm{cm})$, ear height $(\mathrm{cm}), 100$ seed weight $(\mathrm{g})$ and shelling (\%) whereas days to $50 \%$ tasseling, days to $50 \%$ silking days to $75 \%$ dry husk were recorded on visual basis per plot while number of cobs and cob weight measured from plot basis. The grain yield $(\mathrm{kg} /$ ha.) for each genotype was estimated by reducing grain moisture content to $15 \%$ with step wise formula. (a) grain yield at observed grain moisture content $[\square$ cob yield (kg/plot) at harvest $\mathrm{x}$ Multiple factor for ha $\mathrm{x}$ shelling proportion (\%)], (b) grain dry matter content $=1-$ moisture per cent at harvest, (c) grain yield at $15 \%$ grain moisture content $=[$ (grain yield at observed grain moisture content $\mathrm{x}$ grain dry matter content)/0.85], (d) grain yield at $15 \%$ grain moisture content $=[$ (grain yield at $15 \%$ grain moisture content)/100]. The mean of the data recorded over years were used for statistical analysis. The analysis of variance was calculated with the method suggested by Panse and Sukhatme, 1985. The statistical analysis for $G \times E$ interaction and stability parameters were carried out according to the Eberhart and Russell (1966).

\section{Results and Discussion}

The presence of $\mathrm{G} \times \mathrm{E}$ interactions reduces the correlation between phenotype and genotype, and makes it difficult to judge the genetic potential of a genotype. Stability of a cultivar refers to its consistency in performance across environments and is affected by the presence of $\mathrm{G} x \mathrm{E}$ interactions. In presence of significant $\mathrm{G} \times \mathrm{E}$ interactions, stability parameters are estimated to determine the superiority of individual genotypes across the range of environments. Eberhart and Russell (1966) defined a stable genotype as one which produces high mean yield, depicts regression coefficients $\left(b_{i}\right)$ around unity and non-significant deviations from regression $\left(S^{2} d_{i}\right)$.

The linear response $\left(b_{i}\right)$ should be simply regarded as a measure of response of a particular genotype, whereas the deviation from regression $\left(\mathrm{S}^{2} \mathrm{~d}_{\mathrm{i}}\right)$ is regarded as a measure of stability. Becker et al., (1982) regarded mean square for deviation from regression $\left(\mathrm{S}^{2} \mathrm{~d}_{\mathrm{i}}\right)$ to be the most appropriate criterion for measuring phenotypic stability in an agronomic sense because this parameter measures the predictability of genotypic reaction to environments. 
The Analysis of variance for individual environment revealed significant mean squares due to genotypes for days to $50 \%$ pollen shed, cob weight per plot, 100 seed weight and grain yield per hector in all tested years (Table 1). In pooled analysis of variance, the genotypic variance were significantly higher for plant height, ear height and grain yield, whereas environmental variances were significantly high for all the characters. The variances due to $\mathrm{G} \times \mathrm{E}$ interaction were observed significant for all the traits except ear height. This indicated very high influence of environments on the expression of yield and attributing traits in maize land races under study (Table 2). The analysis of variance for stability (Table 3) showed that mean squares due to environments were statistically significant for all the traits except grain yield indicating that variability among environments was large enough for a proper estimation of ' $b$ ' values. The $\mathrm{G} \times \mathrm{E}$ interaction was significant for four traits viz., plant height, ear height, cob weight and shelling percentage. Such significant interaction encourage maize breeder to develop variety/hybrid under varied environment condition. Therefore, stability parameters of the land races worked out for these four characters (Table 5). Similar findings in maize were also reported by Nirla and Jha (2003), Soliman (2006), Dadheech and Joshi (2007) and Patel (2015) for yield and yield attributing traits.

The environment + (genotype $\mathrm{x}$ environment) interaction was also observed to be significant for all traits except number of cobs per plot and grain yield per ha. Indicating considerable interaction of genotype with environment and the distinct nature of environment and genotype $\mathrm{x}$ environment interaction in phenotypic expression. Further, partitioning of the environment + (genotype $x$ environment) component into environment (linear) revealed the significance of environment (linear) component for all the traits except days to $75 \%$ dry husk and grain yield per ha, indicating that micro seasonal difference were presented under all the three year studies and forecast over year was possible. The higher magnitude of mean square for environment (linear) as compared to $\mathrm{G} \times \mathrm{E}$ (linear) indicated that linear response of environment accounted for major part of the total variance for all the traits and might be responsive for high adaptation of the genotype in relation to yield and other component trait. Further, the mean square due to genotype $\mathrm{x}$ environment (linear) were also significant for plant height, ear height, cobs, weight per plot and shelling (\%), similar trend in maize for yield attributes also reported earlier Kaundal and Sharma (2006), Lata et al., (2010) and Nadagoud et al., (2012). While in case of mean square for pooled deviation (non-linear) were also observed to be significant for days to $75 \%$ dry husk, number of cobs per plot, cobs weight per plot, 100 seed weight and grain yield. This is indicating that both linear and non-linear component may be contributing to the genotype $\mathrm{x}$ environment interaction observed for these traits. Dadheech and Joshi (2007), Jai Dev et al., (2010) and Patel (2015) also reported similar findings in maize for yield and yield attributing traits.

An overall study of stability parameters revealed that not a single genotype was ideally stable for all the four characters. According to Eberhart and Russell (1966), a stable genotype would have approximately high mean with $\mathrm{b}_{\mathrm{i}}=1$ and $\mathrm{S}^{2} \mathrm{~d}_{\mathrm{i}}=0$. Whereas according to Johnson et al., (1955), Paroda et al., (1973) and Lin et al., (1986) the squared deviation from regression as a measure of a stability while the regression was considered as measure of response, considering these parameter out of 51 land races studies, 15 topranked land races based on stability parameters identified (Table 4). 
Table.1 Analysis of variance for individual environments

\begin{tabular}{|c|c|c|c|c|c|c|c|c|c|c|c|}
\hline $\begin{array}{c}\text { Sources of } \\
\text { variation }\end{array}$ & d.f. & $\begin{array}{c}\text { Days to } \\
50 \% \\
\text { Pollenshed }\end{array}$ & $\begin{array}{c}\text { Days to } \\
50 \% \\
\text { Silking }\end{array}$ & $\begin{array}{c}\text { Days to } \\
75 \% \\
\text { Dryhusk }\end{array}$ & $\begin{array}{c}\text { Plant } \\
\text { Height(cm.) }\end{array}$ & $\begin{array}{c}\text { Ear } \\
\text { Height(cm.) }\end{array}$ & $\begin{array}{c}\text { Number } \\
\text { of Cobs } \\
\text { per Plot }\end{array}$ & $\begin{array}{l}\text { Cob wt. } \\
\text { per Plot } \\
(\mathrm{Kg})\end{array}$ & $\begin{array}{c}\text { 100- } \\
\text { seed } \\
\text { weight }\end{array}$ & $\begin{array}{c}\text { Shelling } \\
(\%)\end{array}$ & $\begin{array}{l}\text { Grain yield } \\
\text { (kg/ha) }\end{array}$ \\
\hline \multicolumn{12}{|c|}{ ENVIRONMENT - I } \\
\hline Replication & 1 & 3.92 & 6.13 & 0.09 & 333.37 & 29.01 & 6.63 & 0.022 & 1.14 & 25.10 & 17323.88 \\
\hline Genotype & 50 & $5.99 *$ & 5.65 & 4.60 & $521.24 *$ & 342.89 & 10.95 & $0.262 * *$ & $18.21^{*}$ & 14.57 & $898715.50 *$ \\
\hline Error & 50 & 3.22 & 3.59 & 5.79 & 272.34 & 219.59 & 7.74 & 0.122 & 10.45 & 12.72 & 525577.28 \\
\hline SEm \pm & & 1.27 & 1.34 & 1.70 & 11.67 & 10.48 & 1.97 & 0.25 & 2.29 & 2.52 & 512.63 \\
\hline \multicolumn{12}{|c|}{ ENVIRONMENT - II } \\
\hline Replication & 1 & 0.48 & 0.09 & 5.65 & 434.41 & 194.36 & 10.04 & 0.257 & 0.19 & 60.57 & 461785.75 \\
\hline Genotype & 50 & $3.87 * *$ & 4.06 & $6.40 * *$ & 272.69 & $276.62 * *$ & 5.33 & $0.159 * *$ & $15.33 * *$ & $186.88 * *$ & $1725060.46 * *$ \\
\hline Error & 50 & 1.46 & 4.19 & 2.89 & 367.44 & 125.05 & 3.94 & 0.071 & 5.93 & 106.56 & 643524.12 \\
\hline SEm \pm & & 0.85 & 1.45 & 1.20 & 17.85 & 7.91 & 1.40 & 0.19 & 1.72 & 7.30 & 567.24 \\
\hline \multicolumn{12}{|c|}{ ENVIRONMENT - III } \\
\hline Replication & 1 & 0.35 & 1.41 & 20.75 & 118.20 & 8.77 & 4.75 & 0.155 & 0.41 & 9.24 & 329872.21 \\
\hline Genotype & 50 & $8.05 * *$ & 10.25 & $18.26^{*}$ & $455.28 * *$ & $309.57 * *$ & $10.12 *$ & $0.56^{* *}$ & $14.69 * *$ & $39.29 * *$ & $2792128.73^{* *}$ \\
\hline Error & 50 & 3.03 & 5.23 & 9.27 & 146.38 & 66.09 & 5.47 & 0.130 & 4.69 & 12.32 & 663670.65 \\
\hline \multicolumn{2}{|l|}{$\mathrm{SEm} \pm$} & 1.23 & 1.62 & 2.15 & 8.56 & 5.75 & 1.65 & 0.26 & 1.53 & 2.48 & 576.05 \\
\hline
\end{tabular}

$*$, ** Significant at $\mathrm{P}=5$ and 1 per cent levels, respectively.

Table.2 Pooled analysis of variance over environments for different characters in maize

\begin{tabular}{|c|c|c|c|c|c|c|c|c|c|c|c|}
\hline $\begin{array}{l}\text { Sources of } \\
\text { variation }\end{array}$ & d.f. & $\begin{array}{c}\text { Days to } \\
50 \% \\
\text { Pollenshed }\end{array}$ & $\begin{array}{c}\text { Days to } \\
50 \% \\
\text { Silking }\end{array}$ & $\begin{array}{c}\text { Days to } \\
75 \% \\
\text { Dryhusk }\end{array}$ & $\begin{array}{c}\text { Plant } \\
\text { Height }(\mathbf{c m} .)\end{array}$ & $\begin{array}{c}\text { Ear } \\
\text { Height(cm.) }\end{array}$ & $\begin{array}{c}\text { Number } \\
\text { of Cobs } \\
\text { per Plot }\end{array}$ & $\begin{array}{c}\text { Cob } \\
\text { wt. per } \\
\text { Plot } \\
(\mathbf{K g})\end{array}$ & $\begin{array}{l}\text { 100-seed } \\
\text { weight }\end{array}$ & $\begin{array}{c}\text { Shelling } \\
(\%)\end{array}$ & $\begin{array}{c}\text { Grain yield } \\
\text { (kg/ha) }\end{array}$ \\
\hline Genotype & 50 & 6.69 & 6.76 & 9.68 & $718.51 * *$ & $590.08 * *$ & 6.42 & 0.368 & 18.75 & 96.95 & $2369360.0 * *$ \\
\hline $\begin{array}{l}\text { Environmen } \\
\mathrm{t}\end{array}$ & 2 & $872.52 * *$ & $740.02 * *$ & $1472.57 * *$ & $31150.39 * *$ & $13123.34 * *$ & $292.17 * *$ & $1.37 * *$ & $1189.20 * *$ & $1013.25 * *$ & $2580829.0 * *$ \\
\hline$G \times E$ & $\begin{array}{r}10 \\
0 \\
\end{array}$ & $5.61 * *$ & $6.60 * *$ & $9.83 * *$ & 265.35 & 169.50 & $9.99 * *$ & $0.306 * *$ & $14.74 * *$ & $71.89 * *$ & 1523272.** \\
\hline Pooled error & $\begin{array}{r}15 \\
0\end{array}$ & 2.57 & 4.34 & 5.98 & 352.05 & 136.91 & 5.72 & 0.108 & 7.02 & 43.87 & 610924.0 \\
\hline
\end{tabular}

*, ** Significant at 5 and 1 per cent levels, respectively when tested against pooled error. 
Table.3 Analysis of variance (mean squares) for stability for various traits in maize

\begin{tabular}{|c|c|c|c|c|c|c|c|c|c|c|c|}
\hline Sources of variation & d.f. & $\begin{array}{c}\text { Days to } \\
50 \% \\
\text { Pollenshed } \\
\end{array}$ & $\begin{array}{c}\text { Days to } \\
50 \% \\
\text { Silking } \\
\end{array}$ & $\begin{array}{c}\text { Days to } \\
75 \% \\
\text { Dryhusk } \\
\end{array}$ & $\begin{array}{c}\text { Plant } \\
\text { Height } \\
\text { (cm.) } \\
\end{array}$ & $\begin{array}{c}\text { Ear Height } \\
\quad(\mathrm{cm} .)\end{array}$ & $\begin{array}{l}\text { Number } \\
\text { of Cobs } \\
\text { per Plot } \\
\end{array}$ & $\begin{array}{c}\text { Cob wt. } \\
\text { per Plot } \\
(\mathrm{Kg}) \\
\end{array}$ & $\begin{array}{l}\text { 100-seed } \\
\text { weight }\end{array}$ & $\begin{array}{c}\text { Shelling } \\
(\%)\end{array}$ & $\begin{array}{c}\text { Grain yield } \\
\text { (kg/ha) }\end{array}$ \\
\hline Genotypes & 50 & 3.34 & 3.38 & 4.84 & $359.26 * *$ & $295.04 * *$ & 3.21 & $0.184 * *$ & 9.37 & $48.47 * *$ & 1184682 \\
\hline Environments & 2 & $436.26 * *$ & $370.01 * *$ & $736.28 * *$ & $15575.27 * *$ & $6551.63 * *$ & $146.09 * *$ & $0.686 * *$ & $594.59 * *$ & $506.58 * *$ & 1290455 \\
\hline $\mathbf{G} \times \mathbf{E}$ & 100 & 2.81 & 3.30 & 4.91 & $132.67 * *$ & $84.75 * *$ & 5.00 & $0.15^{*}$ & 7.37 & $35.95 * *$ & 761635.3 \\
\hline$E+(G \times E)$ & 102 & $11.30 * *$ & $10.49 * *$ & $19.26 * *$ & $435.47 * *$ & $211.75 * *$ & 7.76 & $0.16^{*}$ & $18.89 * *$ & $45.18 * *$ & 772004.3 \\
\hline Environment(Linear) & 1 & $872.5 * *$ & $740.02 * *$ & 1472.55 & $31150.54 * *$ & $13123.27 * *$ & $292.17 * *$ & $1.37 * *$ & $1189.14 * *$ & $1013.16^{* *}$ & 2580910 \\
\hline $\begin{array}{l}\text { Genotype x } \\
\text { Environment } \\
\text { (Linear) }\end{array}$ & 50 & 3.12 & 3.79 & 2.90 & $216.17 * *$ & $136.14 * *$ & 2.89 & $0.21 * *$ & 7.82 & $57.21 * *$ & 626183.4 \\
\hline Pooled deviation & 51 & 2.44 & 2.76 & $6.79 * *$ & 48.21 & 32.70 & $6.96 * *$ & $0.09 * *$ & $6.78 * *$ & 14.40 & $8794497.3 * *$ \\
\hline Pooled error & 150 & 1.29 & 2.17 & 2.99 & 176.04 & 68.45 & 2.86 & 0.054 & 3.51 & 21.94 & 305462.6 \\
\hline Total & 152 & 8.69 & 8.15 & 14.51 & 410.40 & 239.15 & 6.26 & 0.17 & 15.76 & 46.26 & 907753.5 \\
\hline
\end{tabular}

*, ** Significant at 5 and 1 per cent levels, respectively when tested against pooled deviation

Table.4 Stable land races based on mean, regression coefficient $\left(b_{i}\right)$ and deviation from regression $\left(S^{2} d_{i}\right)$ yield component in maize

\begin{tabular}{|c|c|c|c|c|c|c|c|c|c|c|c|c|c|c|c|c|}
\hline \multirow{2}{*}{$\begin{array}{l}\text { Sr. } \\
\text { No. }\end{array}$} & \multicolumn{4}{|c|}{ Plant Height (cm.) } & \multicolumn{4}{|c|}{ Ear Height (cm.) } & \multicolumn{4}{|c|}{ Cob wt. per Plot (Kg) } & \multicolumn{4}{|c|}{ Shelling (\%) } \\
\hline & Genotype & Mean & $\mathbf{b}_{\mathrm{i}}$ & $\mathbf{S}^{2} d_{i}$ & Genotype & Mean & $\mathbf{b}_{\mathbf{i}}$ & $\mathbf{S}^{2} \mathbf{d}_{\mathrm{i}}$ & Genotype & Mean & $\mathbf{b}_{\mathbf{i}}$ & $S^{2} d_{i}$ & Genotype & Mean & $\mathbf{b}_{\mathbf{i}}$ & $\mathbf{S}^{2} \mathbf{d}_{\mathrm{i}}$ \\
\hline 1. & LR-47 & 206.2 & 0.98 & -80.17 & LR-24 & 85.7 & 1.01 & -56.89 & LR-01 & 1.52 & 1.04 & -0.002 & LR-48 & 82.0 & 0.94 & -20.77 \\
\hline 2. & LR-09 & 192.9 & 1.03 & -66.73 & LR-51 & 97.1 & 0.98 & -60.00 & LR-11 & 1.67 & 1.08 & -0.047 & LR-12 & 78.1 & 0.89 & -20.68 \\
\hline 4. & LR-12 & 202.8 & 1.04 & -150.08 & LR-45 & 121.1 & 0.94 & -38.65 & LR-38 & 1.58 & 0.81 & -0.038 & LR-49 & 64.9 & 1.24 & 218.9 \\
\hline 5 & LR-45 & 207.4 & 0.96 & -34.90 & LR-26 & 98.9 & 0.90 & -64.44 & LR-12 & 1.87 & 1.22 & -0.013 & LR-07 & 77.7 & 1.29 & -16.11 \\
\hline 6 & LR-41 & 205.4 & 1.04 & -137.60 & LR-11 & 95.4 & 0.87 & 45.59 & LR-10 & 1.58 & 0.77 & -0.049 & LR-51 & 82.7 & 0.65 & -9.61 \\
\hline 7 & LR-34 & 200.7 & 0.94 & -162.20 & LR-50 & 117.4 & 1.13 & -58.68 & LR-32 & 1.80 & 0.61 & 0.113 & LR-27 & 75.8 & 0.59 & -19.93 \\
\hline 8 & LR-21 & 192.4 & 0.93 & -122.6 & LR-09 & 106.1 & 0.83 & 56.57 & LR-51 & 1.96 & 0.57 & 0.137 & LR-39 & 75.1 & 1.45 & -18.89 \\
\hline 9 & LR-11 & 179.9 & 0.92 & -132.9 & LR-01 & 81.5 & 1.19 & 0.74 & LR-48 & 1.65 & 0.46 & 0.059 & LR-25 & 77.2 & 0.51 & 3.06 \\
\hline 10 & LR-03 & 178.5 & 0.91 & -119.5 & LR-03 & 92.8 & 0.77 & 37.30 & LR-07 & 1.54 & 0.37 & $0.204 *$ & LR-08 & 78.4 & 0.47 & -21.27 \\
\hline 11 & LR-28 & 207.1 & 0.89 & -175.4 & LR-32 & 110.3 & 1.24 & -58.70 & LR-03 & 1.79 & 0.30 & -0.050 & LR-06 & 76.0 & 0.43 & -10.29 \\
\hline 12 & LR-32 & 205.3 & 1.13 & -171.1 & LR-48 & 96.9 & 0.75 & -67.20 & LR-09 & 1.74 & 1.81 & 0.005 & LR-45 & 75.7 & 0.43 & -16.98 \\
\hline 13 & LR-48 & 196.9 & 1.14 & -80.2 & LR-39 & 120.6 & 1.25 & -17.69 & LR-23 & 1.65 & 1.82 & 0.024 & LR-37 & 75.7 & 0.36 & -6.02 \\
\hline 14 & LR-15 & 198.2 & 1.16 & -158.3 & LR-22 & 95.8 & 1.27 & -50.9 & LR-34 & 2.00 & 0.06 & -0.053 & LR-19 & 70.5 & 1.71 & 3.14 \\
\hline \multirow[t]{2}{*}{15} & LR-05 & 220 & 1.20 & -167.3 & LR-34 & 110.3 & 0.71 & -42.9 & LR-40 & 1.93 & 1.95 & -0.022 & LR-46 & 77.9 & 1.86 & -21.71 \\
\hline & 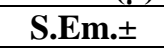 & \multicolumn{3}{|c|}{4.90} & 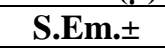 & \multicolumn{3}{|c|}{4.00} & 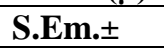 & \multicolumn{3}{|c|}{0.21} & S.Em.土 & \multicolumn{3}{|c|}{2.68} \\
\hline
\end{tabular}


The stability parameters for plant height showed that LR-09 was stable over the environments as it register minimum plant height, unit regression coefficient $\left(b_{i}=1.03\right)$ and non-significant deviation from regression. In case of ear height land race LR-24 and LR51 stood top among all genotype for stability parameter as it registered minimum height (cm), 85.7 and 97.1 respectively, unit regression coefficient and non-significant deviation from regression. The land race LR50 was ideally stable for Cob weight per plot as it exposed higher mean (2.08), near unit regression coefficient $\left(b_{i}=1.17\right)$ and nonsignificant deviation of regression coefficient from zero $\left(\mathrm{s}^{2} \mathrm{~d}_{\mathrm{i}}=-0.047\right)$. In case of Shelling (\%) two land races were found top ranked among stable genotype, viz., LR-48 and LR12 as they registered maximum shelling percentage and fulfill other parameter $\left(b_{i}\right.$ and $\mathrm{S}^{2} \mathrm{~d}_{\mathrm{i}}$ values) of stability. Earlier Kaundal and Sharma (2006), Javed et al., (2006), Jai Dev et al., (2010) and Nadagoud et al., (2012) have also identified stable maize genotype based on phenotypic stability analysis across the environment.

The result of present investigation revealed that since no single land races genotype found stable for all the traits. However LR-09 for plant height, LR-24 for ear height, while LR50, was ideal stable for Cob weight per plot. These land races may further tested at multilocation for confirmation of present findings.

\section{References}

Becker, H.C., Geiger, H.H. and Morgansterm, K. 1982. Performance and phenotypic stability of different hybrid types in winter rye. Crop Sci., 22: 340-344.

Dadheech, A. and Joshi, V.N. 2007. Stability analysis for quality traits in maize ( $\mathrm{Zea}$ mays L.). Agric. Sci. Dig., 27(1): 26-29.

Dhillon, B. S. and Prasanna, B. M., 2001. Maize; In Breeding Field Crops; Theory and Practice edited by V. L. Chopra (ed.): Oxford and IBH, New Delhi. Pp. 147-189.

Doebley, J. F., Gaut, B. S., Smith, B. D., 2006. Cell, 127: 1309.

Eberhart, S.A. and W.A., Russell, 1966. Stability parameters for comparing varieties. Crop Sci., 6: 36-40.

Jai Dev, Guleria S.K., Lata, S., Kalia, V. Singh Amar, Bhardawaj, C.L., Vedna Kumari and Sood, B.C., 2010. Influence of $\mathrm{G} \times \mathrm{E}$ interaction on seed yield and related traits in maize. International Journal of Agricultural Sciences, 6(1): 54-57

Javed, H.I., Masood, M.A., Chughtai, S.R., Malik, H.N., Hussain, M. and Saleem, A. 2006. Performance of maize genotypes on the basis of stability analysis in Pakistan. Asian J. Pl. Sci., 5(2): 207-210.

Johnson, H.W., H.F. Robinson and R.E. Comstock, 1955. Estimates of genetic and environmental variability in soybeans. Agron. J., 47: 314-318.

Kaundal, R. and Sharma, B.K. 2006. Genotype $\mathrm{x}$ environment interaction and stability analysis for yield and other quantitative traits in maize (Zea mays L.) under rainfed and high rainfall valley areas of the sub mountain. Res. On Crops, 7(1): 171-180.

Lata, S., Guleria, S., Jai Dev, Katna, G., Sood, B.C., Kalia, V. and Anand Singh., 2010. Stability analysis in maize (Zea mays L.) hybrids across locations. Electronic Journal of Plant Breeding, 1(3): 239243.

Lin, C.S., M.R. Binns and L.P. Lefkovitch, 1986. Stability analysis, where do we stand? Crop Sci. 26: 894-900.

Nadagoud Vijay Kumar, Jagadeesha, R.C., Wali, M.C., and Kachapur, R.M., 2012. Genetic studies on stability among maize inbred lines. Karnataka J. Agric. Sci, 25(1): 124-126. 
Nirala, R.B.P. and Jha, P.B. 2003. Phenotypic stability for fodder traits in maize (Zea mays L.). Range Management and Agro forestry, 24(1): 9-13.

Panse, V.G. and P.V. Sukhatme, 1985. Statistical methods for agricultural workers (III ${ }^{\text {rd }} \quad$ Edn.). I.C.A.R. Publication, New Delhi.

Paroda, R.S., K.R. Salaniki and B.S. Chandhary, 1973. Phenotypic stability in oats. Indian J. Genetic and Plant Breed, 33: 92-95.
Patel P.C., 2015. Heterosis, combining ability and stability analysis for kernel yield, its components and quality traits in maize (Zea mays L) over environments. Unpublished Ph.D. Thesis of Anand Agricultural University, Anand.

Soliman, M.S.M. 2006. Stability and environmental interaction of some promising yellow maize genotypes. Res. J. of Agric. and Biological Sci., 2(6): $249-255$

\section{How to cite this article:}

Gami, R.A., J.M. Patel, S.M. Chaudhary and Chaudhary, G.K. 2017. Genotype x Environment Relations and Stability Analysis in Different Land Races of Maize (Zea mays L.). Int.J.Curr.Microbiol.App.Sci. 6(8): 418-424. doi: https://doi.org/10.20546/ijcmas.2017.608.055 